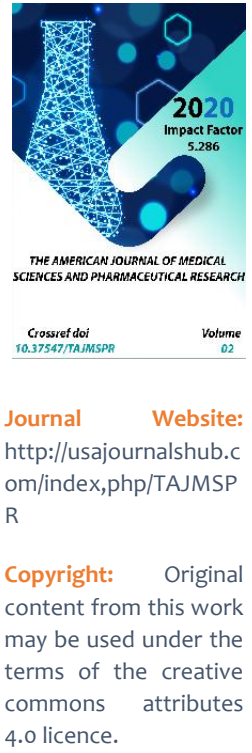

\title{
Ethiopathogenetic Value Of Vitamin D During Heart Rhythm Disorders In Children
}

\author{
Kamola Nigman Kizi Yakubova \\ Department Of Optional Pediatrics, Tashkent Pediatric Medical Institute, Uzbekistan \\ Akida Valievna Muratkhodjaeva \\ Department Of Optional Pediatrics, Tashkent Pediatric Medical Institute, Uzbekistan
}

\section{ABSTRACT}

The article presents the results of clinical and instrumental data of cardiac arrhythmias. Heart rhythm disturbances of any nature change the quality of life. Children are often asymptomatic and often the child's well-being does not suffer for a long time, which greatly complicates the early diagnosis of this pathology and does not allow to accurately establish the duration of the arrhythmia. And in the absence of timely therapy for 4-6 years, most arrhythmias progress, while persistent and irreversible dysfunctions of the myocardium are formed, requiring surgical treatment. To prevent complications, timely diagnosis and treatment is required.

\section{KEYWORDS}

Heart rhythm disorders, children, vitamin D.

\section{INTRODUCTION}

Heart rhythm disturbances in children remain a social problem throughout the world due to the widespread prevalence and progression in subsequent age periods, despite the ongoing therapy, the occurrence of life-threatening conditions such as syncope, acute and chronic 
heart failure, sudden cardiac death $[2,9,10]$. Heart rhythm disturbances remain unresolved until the end of the question of the possible impact on the occurrence and progression of cardiovascular diseases associated with disturbances in the heart rhythm, chemical elements and vitamins $[6,13,15,16,17]$. Heart rhythm disorders of the heart are found in children of all ages. Often the causes of rhythm and conduction disturbances are not only cardiac (myocarditis, cardiomyopathies, pericarditis, primary pathology of the cardiac conduction system), but also extracardiac (diseases of the kidneys, endocrine system organs, impaired autonomic regulation of the heart rhythm), including electrolyte disturbances, poisoning, intoxication xenobiotics, exposure to physical and climatic factors [7]. Research in recent decades has shown that low vitamin D levels are a common problem. Vitamin D deficiency is accompanied by a high risk of developing various chronic diseases [3,4]. Vitamin D deficiency has recently been identified as an independent risk factor for cardiovascular disease. Seasonal fluctuations in mortality from cardiovascular diseases decrease in summer $[5,8]$. This highlights the importance of clarifying the role of vitamin D in the structure of cardiovascular disease. Diseases of the cardiovascular system in childhood form the background for the pathology of the cardiovascular system in adults (ischemic heart disease, hypertension). A significant role of vitamin $D$ deficiency in the development and prognosis of noninflammatory cardiovascular diseases in children was revealed.

A number of non-inflammatory heart diseases in children are associated with insufficient intake or metabolic disorders in the body of minerals (essential, microelements and macroelements), without which many enzymatic processes in the body are impossible $[1,11,12,14]$.

Vitamin D affects the processes of regulation of fat and carbohydrate metabolism, the activity of the renin-angiotensin system, homeostasis of endothelial cells, cardiomyocytes and vascular smooth muscle cells, regulates the activity of a large number of genes for cell proliferation, apoptosis, thus determining the severity of inflammatory processes. With vitamin D deficiency, the stimulation of immune processes, the proliferation and activation of macrophages, $T$ lymphocytes, the release of pro-inflammatory cytokines with the participation of tumor necrosis factors and others develop, and as a result, a cascade of metabolic and immune reactions at the cellular level is triggered.

An imbalance in the level of macronutrients and microelements, vitamin D deficiency affect the contractile ability and the conducting system of the heart and are clinically manifested by disorders $[3,5]$.

Purpose of the study To study the level of vitamin $\mathrm{D}$ in children with cardiac arrhythmias.

\section{MATERIALS AND METHODS}

In total, we examined 40 inpatients of the pediatric cardio-rheumatology department for the period of 2019. Of these, 23 boys (57.5\%), 17 girls (42.5\%). The age composition of the surveyed children was from 1 to 18 years old, among them children aged $1-3$ years - 6 (15\%); 4-7 years - 11 (27.5\%); over 7 years old 23 (57.5\%). An obstetric history was collected. The general clinical examination of the child included a clinical examination, an electrocardiographic study, 24-hour Holter ECG monitoring and all children underwent spectral hair analysis. 


\section{RESULTS OF THE STUDY}

Out of 40 patients, 21 (52.5\%) had cardiac arrhythmias. Moreover, 8 children (38.1\%) were admitted with complaints of rhythm disturbances, the rest of the heart rhythm disturbances were identified during the examination. Rhythm disturbances are most common in the age group over 7 years old. It was found that more often cardiac arrhythmias are found in males 13 (61.9\%). A history of children with arrhythmias often reveals a family history of cardiovascular disease, repeated acute infectious diseases and foci of chronic infection. Rhythm disturbances in children are often asymptomatic, which does not allow us to accurately establish the time of their occurrence. In 13 (61.9\%) cases, arrhythmias were detected accidentally on an electrocardiogram.

Figure 1

The structure of cardiac arrhythmias

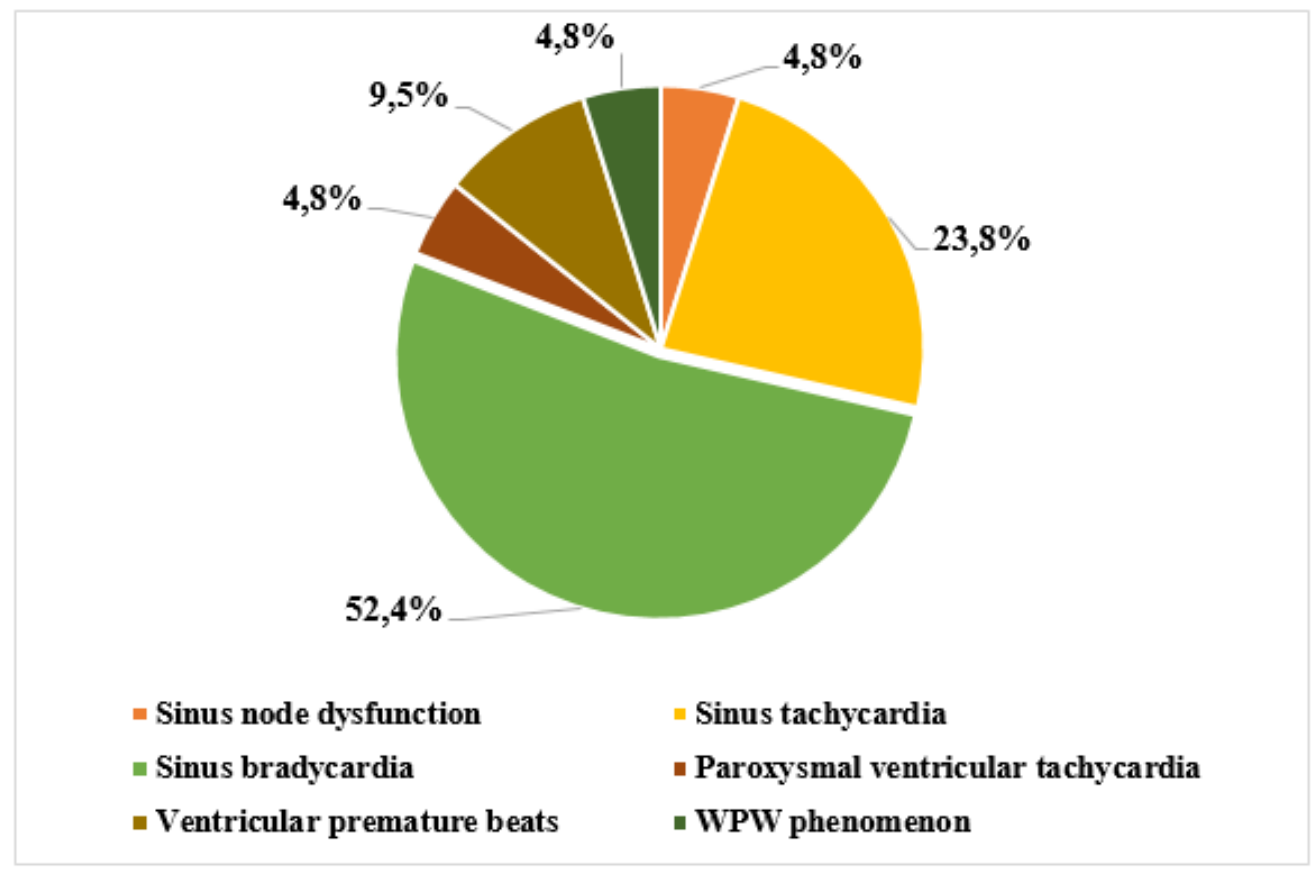

Figure 1. The structure of cardiac arrhythmias looked like this: sinus node dysfunction 1 (4.8\%); sinus tachycardia 5 (23.8\%); sinus bradycardia 11 (52.4\%); paroxysmal ventricular tachycardia 1 (4.8\%); ventricular premature beats 2 (9.5\%); Wolff-Parkinson-White (WPW) phenomenon -1 (4.8\%). Regardless of the form of heart rhythm disturbances, the main complaints are: cardialgia 15 (71.4\%); fatigue 12
(57.1\%); headaches 7 (33.3\%); heartbeat 6 (28.6\%); lack of air 4 (19\%); fainting 1 (4.8\%). In the overwhelming majority of cardiac arrhythmias occur against the background of cardiovascular diseases: secondary cardiomyopathy 2 (9.5\%); congenital heart defects 3 (14.3\%); somotoform vegetativevascular dystonia 11 (52.4\%) and other diseases account for 5 (23.8\%). 
Table 1

Indicator of vitamin D in children depending on nosology

\begin{tabular}{|c|c|}
\hline $\begin{array}{c}\text { Nosology } \\
\text { Heart rhythm } \\
\text { disorders }\end{array}$ & $\begin{array}{c}\text { Vitamin D3, } \\
15,20 \pm 2,93\end{array}$ \\
\hline Norm & $20-65$ \\
\hline
\end{tabular}

The results of assessing the content of vitamin $D$ indicated that children with cardiac arrhythmias were deficient in vitamin D (table 1).

\section{CONCLUSIONS}

Hypovitaminosis D for patients with cardiac arrhythmias is diagnostically significant for the development or progression of this disease. The results obtained confirm the need to correct the vitamin D status for both patients with cardiac arrhythmias and for healthy individuals.

\section{REFERENCES}

1. Carpenter TO, Herreros $\mathrm{F}$, Zhang $\mathrm{JH}$, Ellis BK, Simpson C, Torrealba-Fox E, Kim GJ, Savoye M, Held NA, Cole DE. Demographic, dietary, and biochemical determinants of vitamin $D$ status in innercity children. Am J Clin Nutr. 2012; 95:137-146.

2. Environmental toxic metal contaminants and risk of cardiovascular disease: systematic review and meta-analysis / Rajiv Chowdhury [et al.] // BMJ. - 2018. Vol. 362: k3310.
3. Holick M.F. The vitamin D epidemic and its health consequences. J Nutr 2005;135:2739S-2748S.

4. Holick M.F. Vitamin D deficiency. N Engl J Med 2007;357: 266-281.

5. Melamed M.L., Michos E.D., Post W., Astor B. 25-Hyd roxy vitamin D levels and the risk of mortality in the general population. Arch Intern Med. 2008;168: 1629-1637.

6. Schwedler G. Frequency and spectrum of congenital heart defects among live births in Germany / G.Schwedler // Clin. Res. Cardiol. - 2011. - Vol. 100 (12). - P. 1111-1117.

7. Turner CJ,Wren C. The epidemiology of arrhythmia in infants: a population-based study. J. Paediatr. Child Health. 2011.119:19-31

8. Wang J., Luben R., Khaw K.T., Bingham S., Wareham N.J., Forouhi N.G. Dietary energy density predicts the risk of incident type 2 diabetes: the European Prospective Investigation of Cancer (EPIC) - Norfolk Study. Diabetes Care. 2008; 31:2120-2125.

9. Zitterman A. Vitamin D supplementation enhances the benefi cial effects of weight loss on cardiovascular disease risk 
markers / A.Zitterman // Am. J. Clin. Nutr. - 2009. - Vol. 89. - P. 1321-1327.

10. Artemenkov A.A. Izmenenie klinikofiziologicheskix pokazateley u studentov promishlennogo sentra [Changes in clinical and physiological indicators in students of an industrial center] // Nauchnie vedomosti, seriya Medisina. Farmasiya. NIU «BelGU» [Scientific statements, series Medicine. Pharmacy. NRU "BelGU"]. - 2016. - No. 19 (240), release 35. - P. 67- 71.

11. Vilms Ye. A. Turchaninov D. V., Turchaninova M. S. Mikroelementozi u detskogo naseleniya megapolisa: epidemiologicheskaya xarakteristika i vozmojnosti profilaktiki [Microelementosis in the pediatric population of a metropolis: epidemiological characteristics and prevention possibilities]. // Pediatriya (Jurnal imeni G.N.Speranskogo) [Pediatrics (Journal named after G.N. Speransky)]. - M., 2011. - No. 1. - P. 96-101.

12. Vilms Ye. A. Sravnitelniy analiz mikroelementnogo sostava volos gorodskix jiteley Zapadnoy Sibiri: nauchnoe izdanie [Comparative analysis of the microelement composition of the hair of urban residents of Western Siberia (scientific publication)]. // Gigiena i sanitariya [Hygiene and sanitation]. - M., 2015. - Tom 94 N7G5015. - P. 99-103.

13. Dubovaya A.V. Vliyanie toksichnix i potensialno toksichnix ximicheskix elementov na risk vozniknoveniya aritmii u detey [Influence of toxic and potentially toxic chemical elements on the risk of arrhythmias in children]. // Mat i Ditya v Kuzbasse [Mother and Child in Kuzbass]. - 2016. - No. 3 (66). - P. 15-19.

14. Kurganov V. Ye. Osobennosti soderjaniya mikroelementov $\mathrm{v}$ volosax mladshix shkolnikov $\quad \mathrm{v}$ razlichnix usloviyax antropogennoy nagruzki: nauchnoe izdanie [Features of the content of trace elements in the hair of primary schoolchildren under different conditions of anthropogenic load (scientific publication)] // Gigiena i Sanitariya [Hygiene and sanitation]. - M., 2015. - Tom 94 No. 2. - P. 79-82

15. N.V. Nagornaya, A.V. Dubovaya, Ye.V. Bordyugova [i $\mathrm{d}$ dr.] // Osobennosti soderjaniya makro- i mikroelementov pri zabolevaniyax serdechno-sosudistoy sistemi [Features of the content of macro- and microelements in diseases of the cardiovascular system] (literature review) // Zdorove rebenka [Child health]. - 2012. - No. 4 (39). - P. 30-36.

16. Okuneva G.N. Ximicheskie elementi i strukturno-molekulyarnie osobennosti kardiomiositov u pasientov rannego vozrasta $\mathrm{s}$ transpozisiey magistralnix arteriy [Chemical elements and structural and molecular features of cardiomyositis in young patients with transposition of the great arteries]. // Patologiya krovoobrasheniya i kardioxirurgiya [Circulatory pathology and cardiac surgery]. - 2012. - No. 3. - P. 13-17.

17. Reshetnyak O.A. Znachenie kadmiya, kaliya i kalsiya dlya funksionalnogo sostoyaniya serdechno-sosudistoy sistemi sportsmenov [The value of cadmium, potassium and calsium for the functional state of the cardiovascular system of athletes]. // Uchenie zapiski Tavricheskogo nasionalnogo universiteta im. V. I. Vernadskogo, seriya «Biologiya» [ Scientific notes of the Tavrichesky National University named after V. I. Vernadsky, series "Biology"]. - 2010. - T. 23 (62), No. 3. - P. $129-135$. 